\title{
METODE DAKWAH DALAM MENGUATKAN RESILIENSI KORBAN PENYALAHGUNAAN NARKOTIKA, PSIKOTROPIKA, DAN ZAT ADIKTIF LAINNYA (NAPZA)
}

\author{
Ilmi Hidayati \\ Relawan Peduli Penyandang Masalah Kesejahteraan Sosial Kota Semarang \\ Email: ilmihidayati3@gmail.com
}

\begin{abstract}
Increased drug use is one of the troubling social problems for the population. The impact is felt by mad'u drug abuse whether physical, psychological, spiritual, and social. Mad'u victims of drug abuse is categorized as mad'u with special needs due to physical and psychological conditions experienced an effect on all aspects of life. For that need to develop the psychological strength to recover various impacts due to drug abuse, called the resilience. One way to strengthen the resilience is the da'wah way. Da'wah is a process to invite individuals or groups forming the teachings and Islamic civilization so that the realization of happiness in this world and hereafter. Da'wah serves to invite mad'u misguided and deviated from religious laws or out of nature, in order to return to the path of religion. Meanwhile, to strengthen the resilience of victims of drug abuse, there are several methods used the method of personal approach, method of bi al hal, and counseling methods.
\end{abstract}

\begin{abstract}
$* * *$
Meningkatnya penyalahgunaan Napza merupakan salah satu problem sosial yang meresahkan bagi masyarakat. Dampak penyalahgunaan Napza dirasakan oleh mad'u baik secara fisik, psikologis, spiritual, maupun sosial. Mad'u korban penyalahgunaan Napza dikategorikan sebagai mad'u dengan kebutuhan khusus karena kondisi fisik dan psikologis yang dialami berpengaruh terhadap segala aspek kehidupan yang dijalani. Untuk itu perlunya mengembangkan kekuatan psikologis dalam proses pemulihan berbagai dampak yang ditimbulkan akibat penyalahgunaan Napza yang dinamakan dengan resiliensi. Salah satu cara untuk menguatkan resiliensi yaitu dengan jalan dakwah. Dakwah merupakan proses untuk mengajak individu atau kelompok membentuk ajaran dan peradaban Islam sehingga terwujudnya kebahagiaan di dunia dan akhirat. Dakwah berfungsi untuk mengajak mad'u yang sesat dan menyimpang dari syariat agama atau keluar dari fitrahnya, supaya kembali kepada jalan agama. Sementara untuk menguatkan resiliensi korban penyalahgunaan Napza, terdapat beberapa metode yang digunakan yaitu metode personal approach, metode bi al hal, dan metode konseling.
\end{abstract}

Keywords : drug use, resilience and da'wah 


\section{A. Pendahuluan}

Masalah penyalahgunaan Narkotika, Psikotropika, dan Zat adiktif lainnya $(\mathrm{NAPZA})^{1}$ semakin meningkat pesat ${ }^{2}$. Meningkatnya penyalahgunaan Napza merupakan salah satu ketegangan psikososial sebagai dampak globalisasi yang dianggap sebagai gejala the agony of modernization. ${ }^{3}$ Kondisi globalisasi yang berdampak luas pada kehidupan masyarakat membawa perubahan dalam berbagai segi tatanan kehidupan manusia mulai dari cara berpikir, bersikap, dan bertingkah laku. ${ }^{4}$ Salah satu perubahan life style masyarakat yaitu penyalahgunaan Napza yang telah menjadi frame berpikir sebagian masyarakat ketika menghadapi problem atau tekanan.

Padahal penyalahgunaan Napza berdampak serius baik pada fisik, pikiran, perasaan, fungsi mental, dan perilaku seseorang. Tidak hanya itu, dampak yang diakibatkan oleh penyalahgunaan Napza merambah baik bagi diri pribadi, keluarga, masyarakat, maupun bangsa dan Negara. ${ }^{5}$ Selain itu, agama Islam telah melarang dan sangat peduli akan problematika Napza seperti dalil Al-Qur'an dalam surat Al-Maidah ayat 90:



1 Istilah Napza merupakan akronim dari narkotika, psikotropika, dan zat adiktif lainnya. Penulis menggunakan istilah Napza merujuk pada Kementerian Kesehatan dan Kementerian Sosial yang menggunakan istilah Napza sebagai pengganti istilah zat psikoaktif karena seiring dengan meningkatnya pengetahuan manusia serta luasnya penyalahgunaan zat kimia. Lihat dalam "Keputusan Menteri Kesehatan Republik Indonesia No. 422/MENKES/SK III/2010", hlm. 5

2 Di Indonesia, masalah penyalahgunaan Napza semakin meresahkan. Data Badan Narkotika Nasional (BNN) menyebutkan bahwa pada tahun 2015 prevalensi Napza mencapai 2,8\%. Adapun data rehabilitasi mencapai 1.593 yang tahun sebelumnya hanya 1.123 pecandu dan penyalahguna yang di rehabilitasi (BNN, 2015), hlm. x

${ }_{3}$ Dadang Hawari, Al-Qur'an: Ilmu Kedokteran Jiwa dan Kesehatan Jiwa, (Jakarta : Dana Bhakti Prima Yasa, 1997), hlm. 3

${ }^{4}$ M. Jakfar Puteh, Dakwah di Era Globalisasi Strategi Menghadapi Perubahan Sosial, (Yogyakarta : AK Group, 2006), hlm. 132

5 Partodiharjo, Kenali Narkoba dan Musuhi Penyalahgunaannya, (Jakarta : Esensi, 2010), hlm. 31-34 


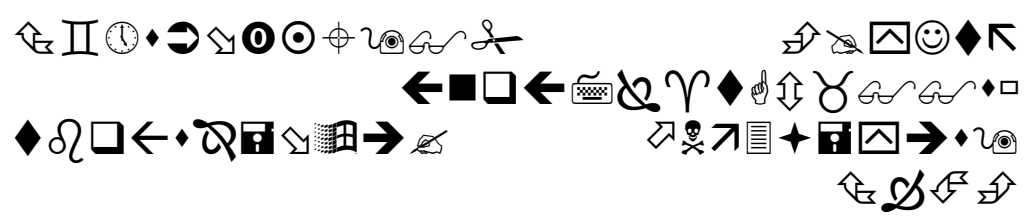

"Hai orang-orang yang beriman, sesungguhnya (meminum) khamar, berjudi, (berkorban untuk) berhala, mengundi nasib dengan panah adalah termasuk perbuatan syaitan. Maka jauhilah perbuatan-perbuatan itu agar kamu mendapat keberuntungan". ${ }^{6}$

Melalui dalil tersebut, telah jelas mengenai larangan akan penyalahgunaan Napza. Akan tetapi berbagai faktor penyebab penyalahgunaan Napza baik secara internal maupun eksternal menjadikan banyak korban yang terjerumus di dalamnya. Salah satu faktor penyebab internal yaitu rendahnya religiusitas seseorang.7 Hawari mengemukakan bahwa anak-anak yang kondisi sekolahnya tidak baik dan terutama muatan pendidikan agama serta budi pekerti yang kurang, maka cenderung ke arah penyalahgunaan Napza. ${ }^{8}$ Selain itu keluarga yang religiusitasnya rendah biasanya kurang menekankan moral dan etika sosial yang berlaku. Pola asuh yang digunakan cenderung permisif sehingga anak seringkali tidak tahu batasan mana yang boleh dilakukan dan mana yang tidak. ${ }^{9}$ Dengan

${ }^{6}$ Ayat tersebut menjelaskan akan larangan khamr, Adapun Napza telah diqiyaskan sebagaimana khamr. Lihat Al-Maraghi dalam Tafsir Al-Maraghi, terj. Anshari Umar Sitanggal, Hery Noer Aly, \& Bahrun Abubakar, (Semarang: Toha Putra), 1992, hlm. 34. Dalam tafsir tersebut dijelaskan bahwa hikmah diharamkan khamr secara bertahap karena orang-orang pada permulaan Islam sangat tergila-gila kepadanya. Sehingga jika pada masa itu khamr diharamkan secara tegas, tentulah hal itu akan membuat pecandunya berpaling dari Islam. Pertama, di dalam surat Al-Baqarah, diharamkan dengan cara member keluasaan untuk berijtihad, sehingga orang belum mencandu akan meninggalkannya. Kedua, di dalam surat An-Nisa', pengharamannya hanya dalam waktu-waktu menjelang shalat. Sebab mereka dilarang mendekati shalat dalam keadaan mabuk. Dengan demikian, orang yang mencandu hanya akan meminumnya setelah melaksanakan shalat isya', dan ini sedikit sekali bahayanya. Kemudian Allah membiarkan mereka dalam keadaannya itu untuk beberapa masa, hingga agama menjadi kuat dan banyak terjadi peristiwa yang dengan itu mereka dapat melihat sendiri dengan jelas dosa dan bahaya meminum khamr. Setelah itu Allah baru mengharamkan secara tegas dan ketat.

7 Iyus Yosep, Keperawatan Jiwa, (Bandung : Refika Aditama, 2010), hlm. 141

8 Dadang Hawari, Penyalahgunaan Ketergantungan NAZA (Narkotika, Alkohol \& Zat Adiktif) Edisi Kedua, (Jakarta : FKUI, 2009), hlm. 33

${ }^{9}$ Abdul Wahib, Menuju Sekolah Bersih dari Narkoba, (Semarang : Pustaka Zaman), hlm. 33 
demikian rendahnya religiusitas menyebabkan individu tidak mampu membentengi diri dari tindak penyalahgunaan Napza.

Berangkat dari faktor penyebab dan dampak yang diakibatkan penyalahgunaan Napza, maka terus mengundang berbagai upaya penyelesaian. Upaya penanggulangan Napza secara garis besar meliputi upaya preventif, represif, dan rehabilitatif. ${ }^{10}$ Usaha penanggulangan yang dilakukan sekarang yang nampak jelas adalah upaya rehabilitasi. Upaya rehabilitasi sangat penting dilakukan karena adanya stigma negatif dari masyarakat kepada korban penyalahgunaan Napza.

Rehabilitasi secara umum bertujuan untuk bertujuan untuk memotivasi pecandu untuk melakukan perubahan ke arah positif yang terdiri dari upaya-upaya medik, bimbingan mental, psikososial, pendidikan, latihan vokasional, dan keagamaan untuk meningkatkan kemampuan yang sesuai dengan potensi yang dimiliki. Selain itu, menciptakan lingkungan yang kondusif bagi mereka yang pada akhirnya diharapkan dapat kembali berinteraksi dengan masyarakat secara wajar. Rehabilitasi juga berfungsi untuk membangun kekuatan psikologis agar ex-pecandu dapat merasa siap mental rohaniah guna menyesuaikan diri dalam lingkungan sosial.11

Pada kenyataannya banyak pecandu ketika masa rehabilitasi maupun setelah rehabilitasi, tidak kuat dalam menghadapi berbagai tantangan kehidupan dan akhirnya timbul perasaan rindu dan keinginan yang kuat (suggest) untuk kembali menggunakan Napza atau relapse. ${ }^{12}$ Sementara mantan pecandu yang kembali ke lingkungan keluarga, lingkungan tempat tinggal, dan lingkungan kerja mengalami reaksi dan hambatan dalam berinteraksi yang berasal dari stigma negatif yang ada dalam masyarakat yang dapat memperbesar kemungkinan terjadinya relapse. Selain itu, godaan lingkungan sekitar atau teman sebaya yang sebagian besar juga pecandu menyebabkan mantan pecandu berpotensi kembali menggunakan Napza. ${ }^{13}$ Hal tersebut menunjukkan bahwa pada fase rehabilitasi maupun setelah rehabilitasi, pecandu kesulitan mempertahankan diri untuk bersih dari Napza.

Menyadari pentingnya upaya penanganan untuk memulihkan berbagai dampak yang ditimbulkan akibat penyalahgunaan Napza serta mencegah kembali agar tidak relapse maka dibutuhkan suatu kemampuan

10 http://dedihumas.bnn.go.id, diakses 17 Februari 2016

11 Agoes Dariyo, Psikologi Perkembangan Remaja, Bogor : Ghalia Indonesia, 2004), hlm. 38 .

12 Partodiharjo, Kenali Narkoba dan Musuhi..., hlm. 106

13 Azmiyati, Siti Riza, dkk, “Gambaran Pengguna Napza Pada Anak Jalanan di Kota Semarang", Jurnal Kesehatan Masyarakat: 2014, hlm. 142 
psikologis yang dinamakan dengan resiliensi. Resiliensi adalah kemampuan seseorang untuk bangkit kembali dari stres atau trauma. ${ }^{14}$ Setiap individu mempunyai sikap tangguh (resilien) secara alami, akan tetapi sikap tersebut harus diasah agar menjadi kuat. Penguatan resiliensi perlu dilakukan karena dengan adanya resiliensi, korban penyalahguna Napza mampu bertahan dan berkembang, serta mempunyai kekuatan untuk pulih kembali.

Berangkat dari realitas tersebut, maka dakwah Islam sudah seyogyanya ikut memberikan kontribusi dalam menanggapi problematika sosial tersebut. Eksistensi gerakan dakwah merupakan bagian yang tak terpisahkan dan senantiasa bersentuhan dengan masyarakat tempat dakwah tersebut dilaksanakan. Oleh karena itu, dakwah selalu melibatkan unsur masyarakat dengan berbagai problema yang dihadapinya. ${ }^{15}$ Menyikapi problematika penyalahgunaan Napza, maka bagaimana metode dakwah yang memungkinkan bisa dilakukan untuk menanggulangi problem tersebut. Tujuannya dalam kajian ini adalah menemukan metode dakwah yang bisa dikembangkan untuk membantu dalam menguatkan resiliensi korban penyalahgunaan Napza. Dalam mengkaji permasalahan di atas, maka penelitian ini menggunakan metode kepustakaan (library research) dan analisis deskriptif.

\section{B. Faktor Penyebab dan Dampak Penyalahgunaan Narkotika, Psikotropika, dan Zat Adiktif Lainnya (Napza)}

Proses terjadinya penyalahgunaan Napza mempunyai penyebab yang begitu kompleks, baik yang berasal dari dalam diri sendiri maupun faktor yang datang dari luar. Hawari menyebutkan bahwa penyalahgunaan Napza merupakan hasil dari interaksi antara faktor predisposisi, faktor kontribusi, dan faktor pencetus. Pertama, faktor predisposisi yaitu ketika seseorang tidak mampu berfungsi secara wajar dan efektif di berbagai lingkungan kehidupannya seperti di rumah, sekolah, tempat kerja, ataupun lingkungan pergaulannya. Kedua, faktor kontribusi yaitu ketika seseorang berada dalam kondisi lingkungan seperti keluarga yang tidak baik (disfungsi keluarga). Keluarga yang tidak baik seperti keluarga yang tidak utuh, kesibukan orang tua, dan hubungan interpersonal yang tidak baik.

\footnotetext{
14 Robert B. Brooks, Sam Goldstein, Nurturing Resilience In Our Children, (New York : McGraw-Hill Books, 2002), hlm. 3.

${ }^{15}$ Asep Saeful Muhtadi dan Agus Ahmad Safei, Motode Penelitian Dakwah, (Bandung : Pustaka Setia, 2003), hlm. 15
} 
Dan ketiga, faktor pencetus yang merupakan pengaruh lingkungan, seperti teman sebaya dan tersedianya dan mudahnya diperoleh Napza. ${ }^{16}$

Selanjutnya Wahib menyebutkan beberapa faktor penyebab seseorang menyalahgunakan Napza yaitu: 1) faktor lingkungan yaitu faktor yang berasal dari luar diri sendiri yang meliputi: hubungan ayah dan ibu yang retak (broken home), komunikasi antara orang tua dan anak yang kurang efektif, adanya anggota keluarga yang tergolong pemakai Napza secara berlebihan, keluarga yang kurang religius atau tidak dekat dengan Tuhannya, teman sebaya, sekolah, dan kemudahan untuk mendapatkan Napza di lingkungannya. 2) Faktor dari dalam individu yang meliputi: adanya gangguan kepribadian, motivasi remaja menggunakan Napza, karakteristik fase perkembangan, dan cara berpikir atau keyakinan yang keliru. 3) Faktor-faktor penyebab menurut pendekatan meliputi: mycrosistem yaitu lapisan yang paling dekat dengan individu, mesosystem yaitu interaksi antar komponen mikrosistem, exosystem yaitu interaksi yang lebih luas, dan macrosystem yaitu lingkungan yang paling luar yang berisi nilai-nilai kultural, adat-istiadat, situasi politik, dan hukum. ${ }^{17}$

Selain beberapa faktor tersebut, penyebab penyalahgunaan Napza merupakan dampak globalisasi yaitu munculnya sikap materialisme, konsumerisme dan hedonisme di kalangan masyarakat, terjadinya anomali atau keterasingan manusia baik terhadap dirinya, lingkungan, dan Tuhannya. ${ }^{18}$ Dari berbagai pengamatan dan penelitian penyalahgunaan Napza, Lukito mengambil kesimpulan bahwa faktor-faktor yang menyebabkan terjadinya penyalahgunaan Napza bersumber dari dua arah, yaitu faktor eksternal dan internal. ${ }^{19}$

Selain kompleksnya faktor yang memengaruhi penyalahgunaan Napza, pada dasarnya dampak yang diakibatkan dari penyalahgunaan Napza juga menjadi masalah yang kompleks. Dampak yang paling ringan ditimbulkan bagi diri penyalahguna Napza seperti perasaan sensitif dan perhatian terhadap lingkungan terganggu dan gangguan pengendalian diri. Sementara dampak penyalahgunaan Napza akan menjadi berat apabila telah meluas ketika penyalahgunaan Napza tidak saja merugikan bagi diri si penyalahguna tetapi juga bagi keluarganya, masyarakat, dan bangsanya. Meningkatnya tindak kriminalitas dalam masyarakat, baik pencurian,

16 Dadang Hawari, Penyalahgunaan \& Ketergantungan NAZA.., hlm. 24.

17 Abdul Wahib, Menuju Sekolah Bersih.., hlm. vi.

18 Basit, Abdul, Wacana Dakwah Kontemporer, (Yogyakarta : Pustaka Pelajar, 2006), hlm. 61

19 Dwi Yani Lukito, Narkotika: Penanganan dan Pencegahannya, (Semarang, Rotary Club Semarang Central, tth), hlm. 10. 
perampokan, perkosaan, dan pembunuhan sangat erat kaitannya dengan peningkatan masalah penyalahgunaan Napza. ${ }^{20}$

Sudiro juga mengemukakan beberapa dampak yang lebih kompleks yaitu: a) terhadap diri sendiri meliputi merusak kepribadian, menimbulkan sikap apatis, menurunnya semangat belajar, dan menimbulkan kecenderungan melakukan pelanggaran seksual, b) terhadap keluarga meliputi: merusak hubungan dan tali persaudaraan, kehilangan kontrol dan etika, dan mencemarkan nama baik keluarga, c) terhadap masyarakat meliputi: merusak citra lingkungan masyarakat, timbulnya kerawanan sosial di bidang keamanan dan pendidikan, dan timbulnya keresahan di masyarakat, dan d) terhadap bangsa dan Negara meliputi: hilangnya generasi muda yang berkualitas dan terancamnya sistem keamanan, politik, dan budaya bangsa. ${ }^{21}$

Adapun Wahib menjelaskan mengenai dampak penyalahgunaan Napza meliputi: Pertama masalah agama baik menyangkut keimanan (berkurang imannya karena bermaksiat), akhlak (melanggar berbagai norma baik agama, sosial, adat, maupun hukum), syariah Islam (termasuk dalam ancaman hukum) maupun ijtima'iyah islamiyah (mengganggu keamanan maupun ketertiban masyarakat). Kedua, masalah jiwa yang menimbulkan penganiayaan, mengancam jiwa bahkan kematian. Ketiga, masalah akal yaitu Napza merusakkan otak dan menganggu fungsi akal. Keempat, masalah harta menyangkut pemborosan uang, bahkan perbuatan kriminal dengan menipu, mencuri, atau merampok guna mendapatkan uang. Kelima, masalah keturunan yang akan merusak kesejahteraan keluarga. ${ }^{22}$

Berangkat dari pemahaman di atas, dapat diketahui bahwa begitu kompleksnya faktor penyebab baik faktor internal maupun eksternal, serta dampak yang diberikan penyalahgunaan Napza baik pada diri individu, keluarga, masyarakat bahkan bangsa. Problem tersebut pada akhirnya menjadi sebuah sistem, sehingga faktor penyebab dan dampak saling terkait ketika dihadapkan pada proses penanggulangan penyalahgunaan Napza.

\section{Resiliensi Korban Penyalahgunaan Napza}

20 Tina Afiatin, Bagaimana Menghindarkan Diri, hlm. 28.

21 Masruhi Sudiro, Islam Melawan Narkoba, (Yogyakarta : Madani Pustaka Hikmah, 2000), hlm. 42.

22 Abdul Wahib, Menuju Sekolah Bersih, hlm. 70-77. 
Istilah resiliensi berasal dari kata Latin resilire yang berarti melambung kembali. Secara sederhana resiliensi diartikan sebagai kemampuan seseorang untuk bangkit dari keterpurukan atau kemalangan. ${ }^{23}$ Brooks mengartikan resiliensi sebagai sebuah dimensi psikologi untuk menggambarkan individu yang bangkit kembali dari stres, trauma atau diartikan sebagai ketahanan. ${ }^{24}$ Sementara Reivich dan Shatte mendefinisikan resiliensi sebagai kemampuan individu untuk melakukan respon dengan cara yang sehat dan produktif ketika berhadapan dengan adversity atau trauma, hal tersebut sangat penting untuk mengendalikan tekanan hidup sehari-hari. 25

Resiliensi diartikan juga sebagai kemampuan untuk bangkit dengan sukses walaupun mengalami situasi penuh resiko yang tergolong parah. ${ }^{26}$ Dengan demikian, resiliensi dianggap penting untuk memahami dinamika dan sistem kerentanan individu terhadap berbagai guncangan dan gangguan. ${ }^{27}$ Dengan adanya resiliensi, individu mampu bertahan dan berkembang, serta mempunyai kekuatan untuk pulih kembali dari kondisi yang menekan. Selain itu resiliensi membantu individu beradaptasi positif pada keadaan dan lingkungan yang berbeda yang dilalui seseorang dalam kehidupannya. ${ }^{28}$ Dengan proses adaptasi tersebut, diharapkan individu akan mempunyai kemampuan menghadapi kesulitan secara signifkan.

McEwen menambahkan bahwa resiliensi menggabungkan beberapa aspek pertumbuhan pribadi seseorang seperti yang digunakan pada setiap pengalaman yang merugikan, tidak hanya untuk meningkatkan koping tetapi lebih untuk mengatur kehidupan selanjutnya ketika menemukan kesulitan. ${ }^{29}$ Berkaitan dengan hal tersebut maka seseorang didorong agar mempunyai kapasitas untuk mengatasi adanya krisis yang membutuhkan

23 Cohen, D. \& B. L. King Kallimanis, "Resilience in Aging: Concepts, Research, and Outcomes" in Barbara Resnick, Lisa P. Gwyther, Karen Roberto, (Ed.), A Geariatric Mobile Crisis Response Team, (London : Springer, 2011), hlm. 314.

${ }^{24}$ Robert B. Brooks, Sam Goldstein, Nurturing Resilience In..., hlm. 3.

25 Mulyani Nasution, Resiliensi : Daya Pegas Menghadapi Trauma Kehidupan. (Medan : USU Press, 2011), hlm. 3. hlm. 4.

${ }^{26}$ Bonnie Benard, Resiliency: What We Have Learned. (California : Wested, 2004),

27 Lance H. Gunderson, C.S. Holling, Lowell Pritchard, et al., "Resilience of Large-Scale Resources Systems", In Lance H. Gunderson and Lowell Pritchard Jr. (Ed.), Resilience and the Behavior of Large-Scale Systems, (London : Island Press, 2002), hlm. 2.

28 Karol L., Kumpee, Drug Abuse Prevention What Works, (New York : NIH Publication, 1997), hlm. 24.

${ }^{29}$ Kathryn McEwen, Building Resilience at Work, (Australia : Australian Academic Press, 2011), hlm. 2. 
keterbukaan untuk belajar, menerima perubahan, dan kemampuan untuk mengobati intervensi sebagai percobaan atau manajemen adaptif. ${ }^{30}$

Individu yang memiliki resiliensi yang baik akan mampu bangkit dari trauma yang mereka alami. Beberapa aspek dari resiliensi dijelaskan secara berbeda oleh beberapa pakar. Reivich dan Shatte dalam Nasution mengemukakan tujuh aspek resiliensi meliputi: 1) regulasi emosi yaitu kemampuan untuk tetap tenang ketika mengalami tekanan, 2) pengendalian impuls yaitu kemampuan individu untuk mengendalikan keinginan, dorongan, kesukaan, serta tekanan yang muncul dari dalam diri seseorang, 3) optimisme yaitu sikap merasa yakin bahwa kondisi dapat berubah menjadi lebih baik, 4) causal analysis yaitu kemampuan individu untuk mengidentifikasikan secara akurat penyebab dari permasalahan yang mereka hadapi, 5) empati yaitu kemampuan individu untuk membaca dan peduli tanda-tanda kondisi emosional dan psikologis orang lain, 6) selfefficacy menggambarkan perasaan seseorang tentang seberapa efektifnya individu berfungsi dalam kehidupannya, dan 7) reaching out yaitu kemampuan seseorang untuk bisa meraih aspek positif atau mengambil hikmah dari kehidupan setelah kemalangan yang menimpa. ${ }^{31}$

Sementara dalam membentuk resiliensi, dikenal istilah risk factors (faktor resiko) dan protective factors (faktor pelindung) yang merupakan faktor yang memengaruhi resiliensi. Pertama, risk factors yang berasal dari sumber luar dan dalam diri seseorang. Berbagai faktor tersebut yaitu: a) anggota kelompok berisiko tinggi, seperti anak-anak dari keluarga yang serba kekurangan; b) tumbuh di lingkungan yang penuh kekerasan atau tercerabut; c) terlahir memiliki cacat fisik, mengalami trauma fisik atau penyakit; d) mengalami kondisi penuh tekanan dalam jangka waktu yang lama; dan e) menderita trauma. Kedua, protective factors memainkan peranan penting dalam memodifikasi efek lingkungan yang negatif dan membantu menguatkan resiliensi. Protectif factors memainkan peran penting dalam memodifikasi efek negatif lingkungan yang merugikan dan membantu menguatkan resiliensi. ${ }^{32}$

Berdasarkan uraian di atas dapat disimpulkan resiliensi adalah kemampuan individu untuk melakukan respon dengan cara yang sehat dan produktif ketika berhadapan dengan kesulitan atau trauma. Dengan demikian individu yang mempunyai resiliensi maka akan mampu

30 Lance H. Gunderson, C.S. Holling, Lowell Pritchard, et al. "Resilience of LargeScale..., hlm. 7.

${ }^{31}$ Mulyani Nasution, Resiliensi : Daya Pegas..., hlm.17-24.

32 Mulyani Nasution, Resiliensi : Daya Pegas..., hlm.10 
memandang kesulitan bukan menjadi hambatan, melainkan tantangan untuk bangkit dan menemukan makna baru dalam kehidupannya.

\section{Penguatan Resiliensi Korban Penyalahgunaan Napza Dengan Dakwah}

\section{Pengertian Dakwah}

Term dakwah berasal dari kata دعا - يدعو - دعوة yang secara lughawi memiliki kesamaan makna dengan kata al-nida (إلآالنداءرسول) yang berarti menyeru atau memanggil. ${ }^{33}$ Arifin mengartikan dakwah sebagai suatu kegiatan ajakan, baik dalam bentuk lisan, tulisan, tingkah laku dan sebagainya, yang dilakukan secara sadar dan terencana dalam usaha mempengaruhi orang lain, baik secara individual maupun secara kelompok, agar timbul dalam dirinya suatu pengertian, kesadaran, sikap, penghayatan, serta pengamalan terhadap ajaran agama sebagai message yang disampaikan kepadanya tanpa adanya unsur-unsur paksaan. ${ }^{34}$

Selanjutnya Syaikh 'Ali Mahfudz mengartikan dakwah sebagai usaha mendorong atau memotivasi manusia untuk melakukan kebaikan (alkhair), mengikuti petunjuk (al-huda), memerintahkan berbuat ma'ruf (alamr bil ma'ruf), dan mencegahnya dari perbuatan mungkar agar memperoleh kebahagiaan dunia dan akhirat. ${ }^{35}$ Adapun Amrullah Ahmad mendefinisikan dakwah sebagai usaha dan kegiatan orang beriman dalam mewujudkan ajaran Islam dengan cara tertentu kedalam hidup perorangan, kelompok, masyarakat, dan negara sehingga terbentuk komunitas dan masyarakat muslim serta peradabannya. ${ }^{36}$

Berangkat dari beberapa pendapat di atas, maka dakwah Islam bisa merupakan usaha mengajak individu atau kelompok untuk membentuk

33 Ilyas Ismail dan Prio Hotman, Filsafat Dakwah Rekayasa Membangun Agama dan Peradaban, (Jakarta : Prenada Media Group, 2011), hlm. 25

34 Arifin, Psikologi Dakwah: Suatu Pengantar Studi, (Jakarta: Bumi Aksara, 1991), hlm. 16

35 Siti Muriah, Metodologi Dakwah Kontemporer, Yogyakarta : Mitra Pustaka, 2000, hlm. 3

36 Amrullah Ahmad, "Konstruksi Keilmuan Dakwah Dan Pengembangan JurusanKonsentrasi Studi", (Semarang : Walisongo, 2008), hlm. 1 
ajaran dan peradaban Islam sehingga terwujudnya kebahagiaan di dunia dan akhirat.

\section{Kondisi Mad'u Korban Penyalahgunaan Napza}

Obyek dakwah (mad'u) adalah manusia yang menjadi audiens yang akan diajak masuk ke dalam Islam secara kaffah. Mereka bersifat heterogen baik dari sudut ideologi, seperti atheis, animis, musyrik, munafik, bahkan ada juga yang muslim tetapi fasik atau penyandang dosa dan maksiat. Dari sudut lain bisa dibedakan berdasarkan intelektualitas, status sosial, kesehatan, maupun pendidikan. ${ }^{37}$

Upaya mengenal mad'u yaitu dengan memunculkan kesadaran dari dalam diri mad'u baik secara psikologis maupun intelektual. Upaya ini dapat berhasil tergantung seberapa jauh da'i mengenal mad'unya. Salah satu strategi dalam mengenal mad'u yaitu dengan mengetahui kondisi psikologis berupa kecenderungan manusia pada umumnya, kemampuan pikiran, stratifikasi sosial, agama, dan madzhab. Strategi ini perlu dilakukan dalam menyusun pedoman program dakwah dan mengatur langkahlangkah sehingga ketika dakwah dilakukan, $d a^{\prime} i$ dapat menyusun materi

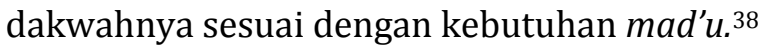

Seperti halnya mad'u korban penyalahgunaan Napza yang bersifat heterogen, tidak hanya non-muslim, akan tetapi banyak umat muslim yang terjerumus pada penyalahgunaan Napza. Hal tersebut bisa terjadi walaupun pada fitrahnya manusia merupakan sebaik-baik ciptaan, akan tetapi manusia mempunyai dua kecenderungan yaitu sifat positif (mahmudah) dan negatif (madzmumah) yang saling berlawanan dan keduanya saling tarik-menarik antara potensi baik dan buruk dalam perangainya. ${ }^{39}$

Sehubungan dengan hal tersebut, maka fungsi dakwah dalam hal ini yaitu mengajak mad'u yang sesat dan menyimpang dari syariat agama atau keluar dari fitrahnya, supaya kembali kepada jalan agama. Selanjutnya mad'u korban penyalahgunaan Napza sebagaimana dijelaskan pada uraian sebelumnya mengenai dampak yang diperoleh, maka termasuk dalam klasifikasi mad'u berkebutuhan khusus. Hal tersebut karena keadaan baik fisik maupun psikis yang tidak bisa disamakan dengan mad'u pada umumnya.

37 Siti Muriah, Metodologi Dakwah Kontemporer, hlm.33

38 M. Ridho Syabibi, Metodologi Ilmu Da'wah Kajian Ontologis Da'wah Ikhwan Al-Safa, Yogyakarta : Pustaka Pelajar. 2008, hlm. 123-124

${ }^{39}$ Suisyanto, Pengantar Filsafat Dakwah, (Yogyakarta : TERAS, 2006), hlm. 86 
Berkaitan dengan itu maka untuk memilih sebuah model agar pesan dakwah dapat dipahami oleh mad'u maka setidaknya harus menggunakan metode sesuai dengan kadar kemampuan dan kebutuhannya. Sehingga mengenal $\mathrm{mad}^{\prime} u$ merupakan salah satu prinsip utama yang harus dimiliki oleh seorang $d a^{\prime} i$ agar dakwah dapat berjalan dengan efektif.

\section{Metode Dakwah sebagai Pendekatan dalam Menguatkan Resiliensi Korban Penyalahgunaan Napza}

Metode adalah cara yang telah diatur dan melalui proses pemikiran untuk mencapai suatu maksud. ${ }^{40}$ Adapun metode dakwah merupakan suatu cara yang digunakan oleh seorang $d a^{\prime} i$ untuk menyampaikan materi dakwah yaitu al-islam atau serentetan kegiatan untuk mencapai tujuan dakwah. ${ }^{41}$ Sementara itu dalam komunikasi metode dakwah lebih dikenal sebagai approach, yaitu cara-cara yang dilakukan oleh seorang $d a^{\prime} i$ atau komunikator kepada mad'u untuk mencapai suatu tujuan tertentu atas dasar hikmah dan kasih sayang. Dengan kata lain, pendekatan dakwah harus bertumpu pada suatu pandangan human oriented yang menetapkan penghargaan mulia pada diri manusia. ${ }^{42}$

Selanjutnya metode dakwah bagi korban penyalahgunaan Napza dianggap penting peranannya karena memengaruhi keefektifan proses dakwah. Sehubungan dengan resiliensi korban penyalahgunaan Napza yang penting dalam proses pemulihan, dakwah mempunyai kontribusi besar khususnya dalam metode dakwah. Adapun terdapat beberapa metode yang dimungkinkan mampu menguatkan resiliensi korban penyalahgunaan Napza, antara lain yaitu:

a. Metode Personal Approach

Pendekatan personal terjadi secara individual yaitu antara $d a^{\prime} i$

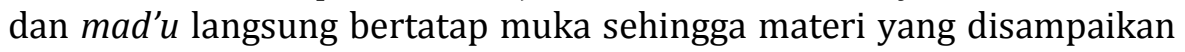
langsung diterima dan biasanya reaksi oleh mad'u akan langsung diketahui. ${ }^{43}$ Metode personal approach didukung dengan metode bil hikmah, bil mauidzah hasanah, dan bil mujadalah.

Pertama, hikmah seringkali diterjemahkan dalam pengertian bijaksana, yaitu suatu pendekatan sedemikian rupa sehingga objek

40 Munzier Suparta \& Harjani Hefni (Ed.), Metode Dakwah, (Jakarta : Prenadamedia Group, 2003), hlm. 6

${ }^{41}$ Aziz, Ali Moh. Ilmu Dakwah, (Jakarta : Kencana, 2004), hlm. 122

42 Toto Tasmara, Komunikasi Dakwah, (Jakarta : Gaya Media Pratama, 1992), hlm. 43

43 Wahidin Saputra, Pengantar Ilmu Dakwah, hlm. 257 
dakwah mampu melaksanakan apa yang didakwahkan atas kemauannya sendiri, tidak merasa ada paksaan, konflik, maupun rasa tertekan. Dalam bahasa komunikasi hikmah menyangkut apa yang disebut sebagai frame of reference, field of reference, dan field of experience, yaitu situasi total yang memengaruhi sikap terhadap pihak komunikan (obyek dakwah). ${ }^{44}$ Kedua, mau'idzah hasanah dapat dimaknai sebagai ungkapan yang mengandung unsur bimbingan, pendidikan, pengajaran, kisah-kisah, berita gembira, peringatan, pesanpesan positif (wasiat) yang bisa dijadikan pedoman dalam kehidupan. ${ }^{45}$ Dan ketiga, al mujadalah merupakan tukar pendapat yang dilakukan oleh dua pihak yang sinergis, yang tidak melahirkan permusuhan dengan tujuan agar lawan menerima pendapat yang diajukan dengan memberikan argumen dan bukti yang kuat. ${ }^{46}$

Ketiga metode tersebut bisa dimasukkan ke dalam personal approach dengan penggunaan mad'u yang berbeda sesuai dengan kepribadiannya. Pada intinya metode personal approach dilakukan secara langsung, termasuk dalam menguatkan resiliensi. Resiliensi mampu dibentuk dengan menjaga protective faktor dan menghindari risk faktor, dengan metode personal approach tersebut $d a^{\prime} i$ memberikan motivasi sesuai dengan problem baik fisik, psikologis, spiritual, maupun sosial kepada mad'u penyalahguna Napza. Dengan metode ini, akan terjalin hubungan yang baik antara da'i dan mad'u yang nantinya akan membantu proses penguatan resiliensi.

b. Metode Bi al Hal

Dakwah bi al hal merupakan aksi nyata dalam kehidupan masyarakat, atau metode pemberdayaan masyarakat, yaitu dakwah dengan upaya untuk membangun daya, dengan cara mendorong, memotivasi, dan membangkitkan kesadaran akan potensi yang dimiliki serta berupaya untuk mengembangkannya dengan dilandasi proses kemandirian. ${ }^{47}$ Dakwah bil hal juga didefinisikan sebagai dakwah yang

44 Toto Tasmara, Komunikasi Dakwah, hlm. 37

45 Wahidin Saputra, Pengantar Ilmu Dakwah, (Jakarta : RajaGrafindo Persada, 2011), hlm. 252

46 Wahidin Saputra, Pengantar Ilmu Dakwah, hlm. 255

47 Moh Ali Aziz, Ilmu Dakwah, hlm. 378 
dilakukan melalui penampilam kualitas pribadi dan aktifitas-aktifitas yang secara langsung menyentuh keperluan masyarakat. 48

Terkait korban penyalahgunaan Napza, saat ini telah banyak rehabilitasi maupun institusi penerima wajib lapor sosial yang mempunyai binaan dengan berbagai keterampilan yang diajarkan. Jadi tidak hanya diberikan pengetahuan dan wawasan keislaman, akan tetapi berbagai skill harusnya diajarkan sesuai dengan bakat dan minat serta kemampuan dari mad'u. Hal ini dimaksudkan agar korban penyalahgunaan Napza mampu mandiri setelah menjalani pemulihan, mempunyai bekal keterampilan serta menghilangkan stigma negatif ketika kembali hidup di masyarakat.

Selain itu, mad'u diajak mengikuti kegiatan positif yang ada di masyarakat, tentunya dengan pendampingan $d a^{\prime} i$. Aksi nyata tersebut memberikan motivasi positif yang kemudian menjadi kekuatan bagi mad'u untuk meneruskan kehidupannya setelah menjalani proses pemulihan. Metode dengan bi al hal ini tentunya bisa menguatkan resiliensi penyalahguna Napza.

c. Metode Konseling

Konseling diartikan sebagai pemberian nasehat, pemberian anjuran, dan pembicaraan dengan bertukar pikiran. ${ }^{49}$ Metode konseling merupakan wawancara secara individual dan tatap muka antara konselor sebagai pendakwah dan klien sebagai mitra dakwah untuk memecahkan masalah yang dihadapinya. Konselor sebagai pendakwah dalam hal ini akan membantu mencari pemecahan masalahnya. 50

Konseling sangat dibutuhkan bagi mad'u khususnya penyalahguna Napza. Meskipun metode personal approach seringkali mewakili pertemuan dengan $\operatorname{mad}^{\prime} u$, akan tetapi metode konseling dirasa lebih intim. Ketika masa pemulihan di lembaga rehabilitasi semisal, ada jadwal tersendiri untuk melakukan konseling. Hal ini dilakukan karena agar konselor atau pendakwah memahami

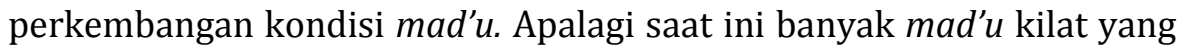

\footnotetext{
48http://burhanuddin63.blogspot.com/2010/04/memahami-danmelaksanadakwah-bil-hal.html, diunduh pada tanggal 27 Februari 2017

${ }^{49}$ Adz Dzaky, Hamdani Bakran. Konseling dan Psikoterapi Islam. Bandung : Rizky Press. 2000, hlm. 179

50 Moh. Ali Aziz, Ilmu Dakwah, hlm. 372
} 
ada di rehabilitasi, artinya mad'u hanya datang ketika melakukan konseling.

Metode konseling pada intinya adalah sebuah metode secara tatap muka untuk memecahkan masalah yang dihadapi oleh mad'u. Banyak teknik yang dipakai dalam konseling, akan tetapi intinya adalah sebagai proses penguatan resiliensi $\operatorname{mad}^{\prime} u$. Ketika mad'u mau menjalani konseling, maka beban psikologis mad'u akan berkurang. Hal ini tentunya sangat berkaitan dengan proses komunikasi yang dilakukan, tidak hanya dengan $d a^{\prime} i$ sebagai konselor akan tetapi dengan semua lingkungan penyalahguna Napza.

\section{Penutup}

Penyalahgunaan Napza merupakan salah satu ketegangan psikososial yang berdampak pada berbagai sendi kehidupan khususnya bagi pribadi korban. Berbagai penderitaan yang dialami baik secara fisik, psikis, spiritual, maupun sosial berakibat pada perasaan tertekan serta melemahnya kemampuan untuk bangkit dari keterpurukan. Dampak tersebut membutuhkan penanganan dalam menguatkan kemampuan resiliensi korban penyalahgunaan Napza. Salah satu cara untuk menguatkan resiliensi yaitu dengan jalan dakwah. Dakwah merupakan proses untuk mengajak individu atau kelompok membentuk ajaran dan peradaban Islam sehingga terwujudnya kebahagiaan di dunia dan akhirat. Dakwah berfungsi untuk mengajak mad'u yang sesat dan menyimpang dari syariat agama atau keluar dari fitrahnya, supaya kembali kepada jalan agama. Sementara untuk menguatkan resiliensi korban penyalahgunaan Napza, terdapat beberapa metode yang digunakan yaitu metode personal approach, metode bi al hal, dan metode konseling. Metode dakwah yang digunakan diharapkan mampu menguatkan resiliensi penyalahguna Napza sehingga mampu bangkit kembali dari berbagai tekanan dan mengadapi kehidupan selanjutnya dengan cara pandang yang lebih baik. 


\section{DAFTAR PUSTAKA}

Afiatin, Tina, "Bagaimana Menghindarkan Diri Dari Penyalahgunaan Napza?", Buletin Psikologi Tahun VI, No.2, Desember, 1998, 28

Adz Dzaky, Hamdani Bakran, Konseling dan Psikoterapi Islam, (Bandung : Rizky Press, 2000)

Ahmad, Amrullah, Makalah "Konstruksi Keilmuan Dakwah Dan Pengembangan Jurusan-Konsentrasi Studi", (Semarang : Walisongo, 2008)

Al-Maragi, Tafsir Al-Maragi, terj. Anshari Umar Sitanggal, Hery Noer Aly, \& Bahrun Abubakar, (Semarang: Toha Putra, 1992)

Arifin, Psikologi Dakwah: Suatu Pengantar Studi, (Jakarta: Bumi Aksara, 1991)

Aziz, Ali Moh. Ilmu Dakwah, (Jakarta : Kencana, 2004)

Azmiyati, Siti Riza, dkk, "Gambaran Pengguna Napza Pada Anak Jalanan di Kota Semarang", Jurnal Kesehatan Masyarakat, 2014, 142.

Basit, Abdul, Wacana Dakwah Kontemporer, (Yogyakarta : Pustaka Pelajar, 2006)

Benard, Bonnie, Resiliency: What We Have Learned. (California : Wested, 2004)

Brooks, Robert B., Sam Goldstein, Nurturing Resilience In Our Children, (New York : McGraw-Hill Books, 2002)

Cohen, D. \& B. L. King Kallimanis, "Resilience in Aging: Concepts, Research, and Outcomes" in Barbara Resnick, Lisa P. Gwyther, Karen Roberto, (Ed.), A Geariatric Mobile Crisis Response Team, (London : Springer, 2011) 
Dariyo, Agoes, Psikologi Perkembangan Remaja, (Bogor : Ghalia Indonesia, 2004)

Gunderson, Lance H., C.S. Holling, Lowell Pritchard, et al., "Resilience of Large-Scale Resources Systems", In Lance H. Gunderson and Lowell Pritchard Jr. (Ed.), Resilience and the Behavior of Large-Scale Systems, (London : Island Press, 2002)

Hawari, Dadang, Al-Qur'an: Ilmu Kedokteran Jiwa dan Kesehatan Jiwa, (Jakarta : Dana Bhakti Prima Yasa, 1997) , Penyalahgunaan \& Ketergantungan NAZA (Narkotika, Alkohol \& Zat Adiktif) Edisi Kedua, (Jakarta : FKUI, 2009)

Ismail, Ilyas, Prio Hotman, Filsafat Dakwah Rekayasa Membangun Agama dan Peradaban Islam, (Jakarta : Kencana, 2011)

Keputusan Menteri Kesehatan Republik Indonesia No. 422/MENKES/SK III/2010

Kumpee, Karol L., Drug Abuse Prevention What Works, (New York : NIH Publication, 1997)

Lukito, Dwi Yani, Narkotika: Penanganan dan Pencegahannya, (Semarang : Rotary Club Semarang, T.tt)

McEwen, Kathryn, Building Resilience at Work, (Australia : Australian Academic Press., 2011)

Muhtadi, Asep Saeful, Agus Ahmad Safei, Motode Penelitian Dakwah, (Bandung : Pustaka Setia, 2003)

Muriah, Siti, Metodologi Dakwah Kontemporer, (Yogyakarta : Mitra Pustaka, 2000)

Nasution, Mulyani, Resiliensi : Daya Pegas Menghadapi Trauma Kehidupan. (Medan : USU Press, 2011)

Partodiharjo, Kenali Narkoba dan Musuhi Penyalahgunaannya, (Jakarta : Esensi, 2010)

Puteh, M. Jakfar, Dakwah di Era Globalisasi Strategi Menghadapi Perubahan Sosial, (Yogyakarta : AK Group, 2006)

Saputra, Wahidin, Pengantar Ilmu Dakwah, (Jakarta : RajaGrafindo Persada, 2011) 
Sudiro, Masruhi, Islam Melawan Narkoba, (Yogyakarta : Madani Pustaka Hikmah, 2000)

Suisyanto, Pengantar Filsafat Dakwah, (Yogyakarta : TERAS, 2006)

Suparta, Munzier, Harjani Hefni (Ed.), Metode Dakwah, (Jakarta : Prenadamedia Group, 2003)

Syabibi, M. Ridho, Metodologi Ilmu Da'wah Kajian Ontologis Da'wah Ikhwan Al-Safa, (Yogyakarta : Pustaka Pelajar, 2008)

Tasmara, Toto, Komunikasi Dakwah, (Jakarta : Gaya Media Pratama, 1992)

Wahib, Abdul, Menuju Sekolah Bersih dari Narkoba, (Semarang : Pustaka Zaman, 2014)

Yosep, Iyus, Keperawatan Jiwa, (Bandung : Refika Aditama, 2010)

http://dedihumas.bnn.go.id, diakses 17 Februari 2016

http://burhanuddin63.blogspot.com/2010/04/memahami-dan-

melaksanadakwah-bil-hal.html, diunduh pada tanggal 27 Februari 2017 